\title{
Impacts of Groundwater Heat Pump System on Microorganism Growth in Beijing Plain, China
}

\author{
Binghua Lij ${ }^{a}$ *, Licai Liü, Qijun Lic ${ }^{b}$, Junxiong Huang ${ }^{d}$, Yong Yang ${ }^{e}$
}

Beijing Water Science \&Technology Research Institute, Untraditional Water resources development and utilization and water saving engineering technology research center, Chegongzhuang west road 21, haidian district,Beijing, 100048, China

alibinghua75@163.com, bl1012@126.com, clqj@bwsti.com, dhjx@bwsti.com, eyy@bwsti.com

Keywords: groundwater heat pump, temperature, $\mathrm{pH}$, bacteria, escherichia coli.

\begin{abstract}
Here one demonstration project of groundwater heat pump (GWHP) system in Beijing plain, China, was selected to study impact of temperature, $\mathrm{pH}$, and ratio of carbon and nitrogen in groundwater on the growth of microorganism. Results showed that $\mathrm{pH}$, and ratio of carbon and nitrogen had little influence, while temperature played an important role. When temperature was higher or lower than $13.2^{\circ} \mathrm{C}$, the amount of Escherichia coli and bacteria showed a decreasing trend roughly consistent with the normal distribution. Meanwhile, based on the monitored data, the relationship between groundwater temperature and the capacity of E. coli and bacteria were summarized.
\end{abstract}

\section{Introduction}

With the increasing demand for renewable energy, groundwater heat pump (GWHP) system is being used more and more widely in the world, especially in Europe and North America. This reason of that phenomenon results from the increasing costs of conventional energy and improving the use of renewable energy with low carbon dioxide production ${ }^{[1]}$. GWHP system is a doublet well open-loop system, pumps groundwater from an extraction well, exploits groundwater calories, and finally dismisses groundwater into an injection well in the same aquifer ${ }^{[2]}$. China is an energy consumption power. Conventional energy resources cannot meet its huge energy demand. Thus it is urgent to apply renewable energy technologies to solve such problem ${ }^{[3]}$. The application of GWHP system becomes a hot topic for researchers. Many researches mainly focus on the application potential, energy efficiency rate, and performance evaluation of GWHP system ${ }^{[4]}$. However, there are relatively few studies on its impact on underground microorganism. Here based on one GWHP demonstration project in Beijing, China, the relationship of temperature, $\mathrm{pH}$ and microorganism growth were analyzed.

\section{The conditions of study area and GWHP systems}

\subsection{The hydrogeological conditions of study area}

The project is located in the edge of Yongding River alluvial fan, Beijing, China, and the aquifers are water-richness. Groundwater flows from west to east with about 3\%o hydraulic gradient. According to the data of pumping test, the output of single well after water level dropping $5 \mathrm{~m}$ is between $3000 \mathrm{~m}^{3}$ and $5000 \mathrm{~m}^{3}$ per day. The strata of study area were showed in Fig.1. The thickness of quaternary strata above Cambrian shale is $72.5 \mathrm{~m}$, and the strata lithology includes medium sand, coarse sand, sand-stone and silt-clay. There are five aquifers with total thickness of $34 \mathrm{~m}$, and buried depth of static groundwater level is $17.5 \mathrm{~m}$.

\subsection{Layout of GWHP systems}

Since the aquifers are water-richness, only two extraction wells can meet the demand of summer cooling and winter heating for the project. According to previous test of single well, the rate of injection water volume and extraction water volume generally ranged from $60 \%$ to $70 \%$. To ensure all extracted groundwater can be recharged to those aquifers, four injection wells were built. 
Meanwhile, the distance between extraction wells and injection wells were designed so far to reduce the impact of groundwater recharge on extraction wells, and to prolong the time of thermal short circuit. In the winter, two extraction wells and four injection wells were all operated to meet heat demand, and to ensure all groundwater recharged to aquifers. However, in summer, only No.1 extraction well, No.3 and No.4 injection wells were in operation because the building required cooling load was less than half of heating load in winter. The layout of building and wells was shown in Fig.2.

\begin{tabular}{|c|c|c|c|}
\hline $\begin{array}{c}\text { bottom } \\
\text { elevation }(\mathrm{m})\end{array}$ & $\begin{array}{c}\text { strata } \\
\text { thickness }(\mathrm{m})\end{array}$ & strata diagram & lithology \\
\hline 22 & 4 & & silt clay \\
\hline 31 & 9 & $::::::::$ & $\begin{array}{l}\text { medium } \\
\text { sand }\end{array}$ \\
\hline 34.5 & 3.5 & & silt clay \\
\hline 38.5 & 4 & $\therefore: \therefore:: \therefore:$ & coarse sand \\
\hline 44 & 5.5 & & silt clay \\
\hline 53 & 9 & $::::::::$ & coarse sand \\
\hline 57 & 4 & & silt clay \\
\hline 60 & 3 & $\therefore:::$ & coarse sand \\
\hline 63.5 & 3.5 & & silt clay \\
\hline 72.5 & 9 & 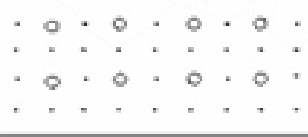 & $\begin{array}{l}\text { sand } \\
\text { stone }\end{array}$ \\
\hline 80.0 & 7.5 & & shale \\
\hline
\end{tabular}

Fig.1 Sketch of strata in the study area

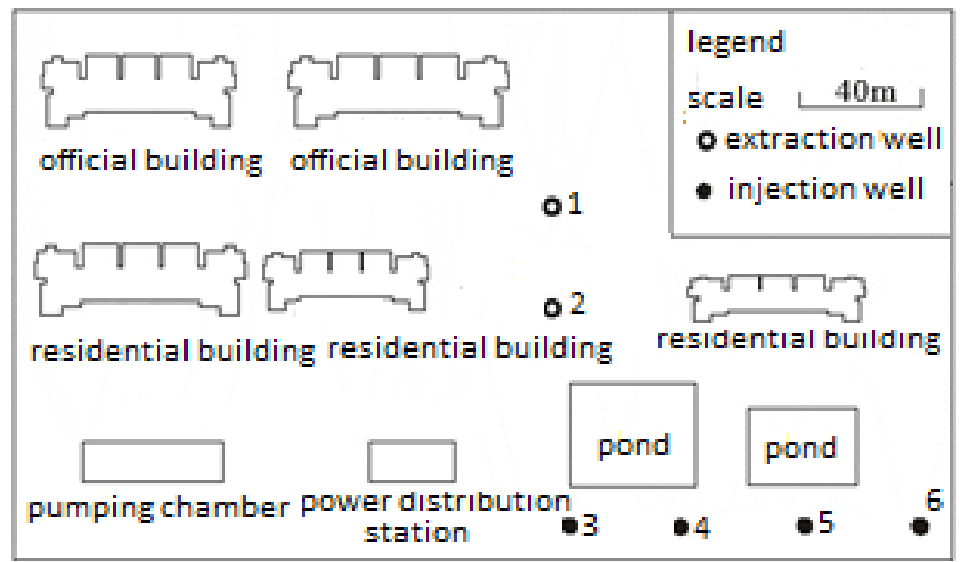

Fig.2 Sketch of GWHP system in the project

\section{Result and discussion}

In natural environment of groundwater, the growth of microorganism was mainly impacted by $\mathrm{pH}$, ratio of carbon and nitrogen $(\mathrm{C}$ and $\mathrm{N})$ and temperature. Based on the data got from the project in winter and summer, $\mathrm{pH}$ value and ratio of $\mathrm{C}$ and $\mathrm{N}$ in groundwater were ranged from 7 to 8.5 , and 0 to 6.5, respectively. Meanwhile other components such as TDS, sulfate, chloride, ammonia nitrogen, iron, etc., were monitored. The data showed that most hydro-chemical components concentrations of 
groundwater during GWHP system operation were relatively stable, and nutrients of groundwater needed for the growth of microorganism did not show a significantly change. The scatter plots of $\mathrm{pH}$, ratio of $\mathrm{C}$ and N, Escherichia coli (E. coli) and bacteria were shown from Fig.3 to Fig.6.

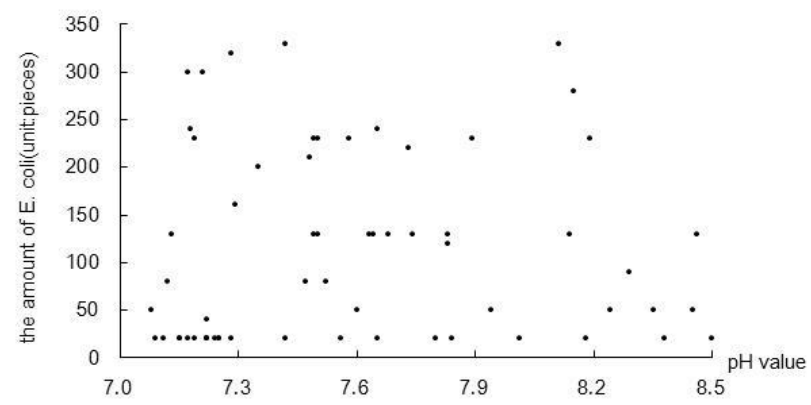

Fig.3 Scatter plot of $\mathrm{pH}$ value and E. coli amount in groundwater

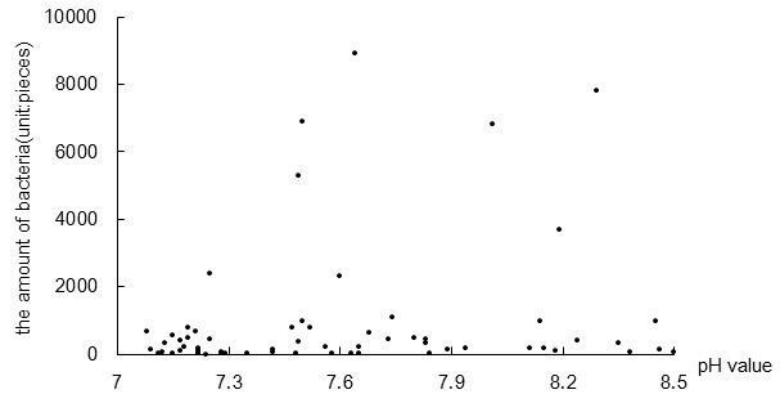

Fig.4 Scatter plot of $\mathrm{pH}$ value and bacteria amount in groundwater

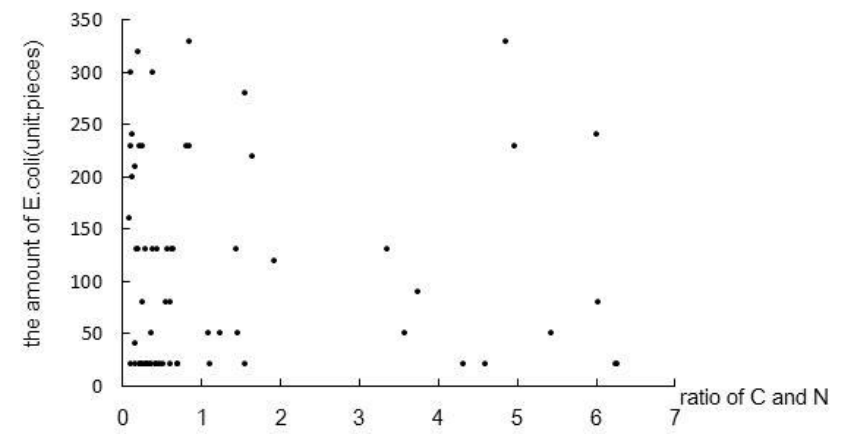

Fig.5 Scatter plot of $\mathrm{C} / \mathrm{N}$ ratio and E.coli amount in groundwater

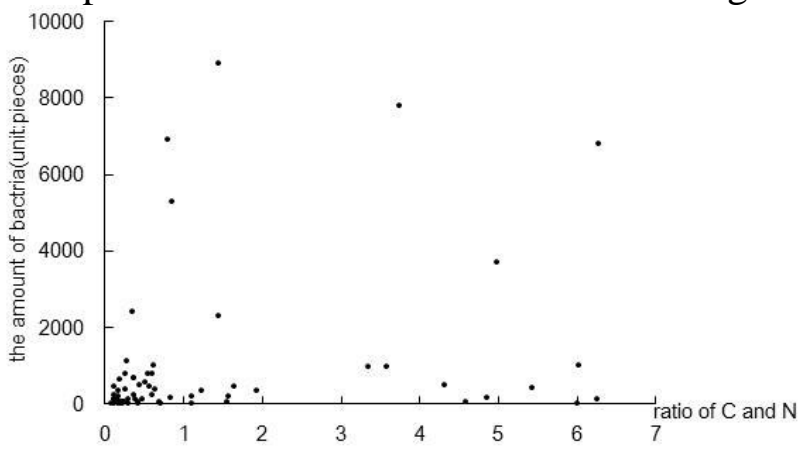

Fig.6 Scatter plot of $\mathrm{C} / \mathrm{N}$ ratio and bacteria amount in groundwater

As can be found, $\mathrm{pH}$ or ratio of $\mathrm{C}$ and $\mathrm{N}$ increasing did not cause obvious variation in the amount of E. coli and bacteria. Furthermore, the higher amounts of E. coli and bacteria distributed randomly and did not relatively focus on one region of $\mathrm{pH}$ or ratio of $\mathrm{C}$ and $\mathrm{N}$. These revealed that hydro-chemical components and nutrients in groundwater during QWHP system operation had little influence on the growth of microorganism.

However, when QWHP system alternately ran for cooling and heating, temperature of groundwater obviously changed, especially that in the vicinity of injection wells. This can be demonstrated by recharged water temperature and predicted temperature of groundwater. Monitored 
temperature of recharged water changed between $5^{\circ} \mathrm{Cand} 23^{\circ} \mathrm{C}$, and the predicted temperature of groundwater nearby injection wells also changed in that interval. As is known, temperature is one of the most important factors influencing the growth of microorganism, and substances such as proteins, nucleic acids, important part of cells, are extremely sensitive to temperature. When temperatures increased, both biochemical reactions rate and growth rate of cell were accelerated. However, these substances may also suffer from irreversible damage when temperature changes too much. That is to say too higher or lower changes of temperature usually inhibit the growth and reproduction of microorganism. Therefore changes of groundwater temperature during GWHP system operation directly impacted the amount of E. coli and bacteria. The scatter plots of groundwater temperature, the amount of E. coli and bacteria were shown in Fig.7 and Fig.8.

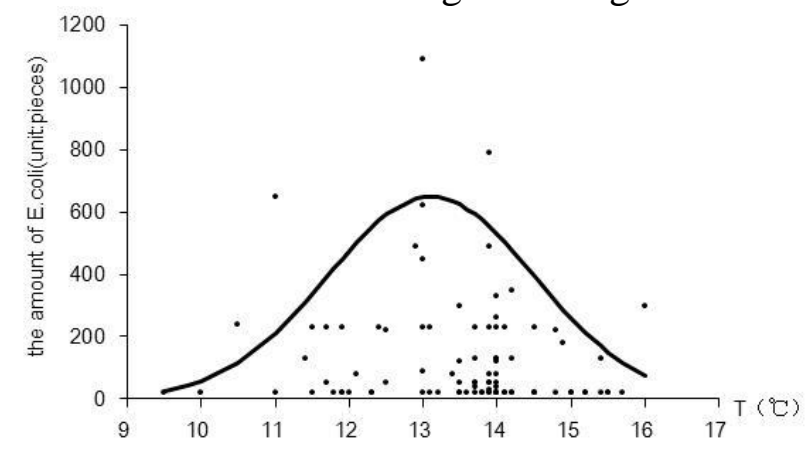

Fig.7 Scatter plot of temperature and E.coli amount in groundwater

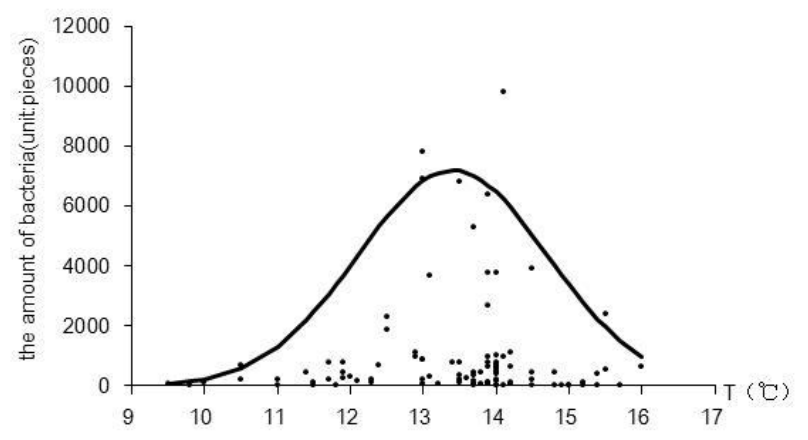

Fig. 8 Scatter plot of temperature and bacteria amount in groundwater

As can be found that the higher amount of E. coli and bacteria relatively were located on the sides of $13.2^{\circ} \mathrm{C}$. When temperature was higher or lower than $13.2^{\circ} \mathrm{C}$, the amount of E. coli and bacteria showed a decreasing trend, which was roughly consistent with the normal distribution. Compared to $\mathrm{pH}$ and $\mathrm{C}$ and $\mathrm{N}$ ratio, temperature influence on the amount of $\mathrm{E}$. coli and bacteria was more significant. In addition, based on those monitoring data, the relationships between groundwater temperature and the capacity of E. coli and bacteria were summarized. They can be described as the following equations:

$$
\begin{aligned}
& K_{E . c o l i}=630 \times \exp \left[-\frac{(T-13.1)^{2}}{2 \times 1.4^{2}}\right] \\
& K_{\text {bacteria }}=7200 \times \exp \left[-\frac{(T-13.4)^{2}}{2 \times 1.3^{2}}\right]
\end{aligned}
$$

\section{Conclusion}

$\mathrm{pH}$ value and ratio of $\mathrm{C}$ and $\mathrm{N}$ in groundwater were ranged from 7 to 8.5 , and 0 to 6.5 , respectively. The change of $\mathrm{pH}$ or ratio of $\mathrm{C}$ and $\mathrm{N}$ did not cause obvious variation in the amount of $\mathrm{E}$. coli and bacteria. Groundwater temperature changed between 50C and 230C. The higher amount of E. coli and bacteria relatively were located on the sides of 13.20C.When temperature was higher or lower than $13.20 \mathrm{C}$, the amount of E. coli and bacteria showed a decreasing trend roughly consistent with the 
normal distribution. Furthermore, the relationship between groundwater temperature and the capacity of E. coli and bacteria were summarized.

\section{Acknowledgments}

Financial support from Beijing Natural Science Foundation (No.8162021) and National Key Project on High Efficient Development and Utilization of Water Resources (No. 2016YFC0401405).

\section{References}

[1] A Galgaro and M Cultrera. Thermal short circuit on groundwater heat pump. Appli Therm Engin 57 (2013) 107-115.

[2] E Milnes and P Perrochet. Assessing the impact of thermal feedback and recycling in open-loop groundwater heatpump (GWHP) systems: a complementary design tool. J Hydro21 (2013):505-514.

[3] Y Ding, X Huang, X.B. Wu and B. Z Li. Investment and economy analysis of water-source heat pump system in Chongqing, China. J Renew Ener, doi:10.1155/2013/574196.

[4] Q. C. Yang, J. Liang, L.C. Liu. Numerical model for the capacity evaluation of shallow groundwater heat pumps in Beijing Plain, China. Proc Environ Sci 10 (2011) 881-889. 